\title{
Interspecific associations of dominant tree populations in a virgin old-growth oak forest in the Qinling Mountains, China
}

Zongzheng Chai ${ }^{1}$, Caili Sun ${ }^{2}$, Dexiang Wang ${ }^{1 *}$ and Wenzhen Liu $^{3}$

\begin{abstract}
Background: Understanding interspecific associations in old-growth forests will help to reveal mechanisms of interspecific replacement in the process of forest development and provide a theoretical basis for vegetation restoration and reestablishment. In this study, we analyzed interspecific associations of eleven dominant tree populations of varying development stages in an old-growth oak forest stand in the Qinling Mountains, China. We examined overall interspecific associations (multiple species) and pairwise interspecific associations (two species).

Results: Interspecific competition was intense during forest development and was the main factor driving succession. Community structure appears to become more stable over time which supports the harsh-benign hypothesis that interspecific competition is more common in stable sites.

Conclusion: Old growth oak (Quercus spp.) forests are distributed widely around the world in part due to oak being a typical K-selected species. K-selected species produce fewer, high-quality offspring with higher survival rates, strong competitive ability, and longevity. The resulting distribution shifted from clumped to random, likely as a result of intense interspecific competition creating ecological niche differentiation.
\end{abstract}

Keywords: Interspecific competition, Quercus aliena var. acutiserrata Maxim., Development stage, Association index, Distribution pattern

\section{Background}

Interspecific associations are the foundation for the formation and evolution of ecological communities (Haukisalmi and Henttonen 1998; Maihaiti and Zhang 2014). They result from species interactions, food chain coactions, as well as similar responses and adaptations to environmental forces (Ofomata et al. 1999; Wang et al. 2010). Species-specific trait differences and unique ecological strategies affect population dynamics and the functioning of entire ecological communities (Wiegand et al. 2007). Measuring interspecific associations can aid in understanding interactions between species, ecological relationships between species, and population

\footnotetext{
*Correspondence: wangdx66@sohu.com

${ }^{1}$ College of Forestry, Northwest A \& F University, No.3 Taicheng Road, Yangling 712100, Shaanxi, People's Republic of China

Full list of author information is available at the end of the article
}

dynamics (Cole 1949; Cabaret and Hoste 1998; Ofomata et al. 1999).

Stable forest or climax vegetation communities are formed by the replacement and development of plant communities. Dramatic shifts in species abundance and composition take place during forest development (Liu et al. 2014). Analyzing development pathways of old-growth forests can provide valuable information on the main drivers of forest development in the absence of anthropogenic influence (Abrams and Copenheaver 1999; Petritan et al. 2014). Species competition and interactions drive the process of forest development. Species that compete with each other are those that occur in the same seral community and require the same habitat conditions (Parrish and Bazzaz 1982). Research on interspecific associations of tree species in old-growth forests will help to reveal mechanisms of interspecific replacement in the process of development and provide a theoretical 
basis for vegetation restoration and reestablishment (Maihaiti and Zhang 2014; Wang et al. 2010).

Mixed forests dominated by oak (Quercus spp.) and pure stands of oak are widely distributed globally. However, oak forests have poor natural regeneration (Cowell et al. 2010; Galbraith and Martin 2005; McCune and Cottam 1985; Nowacki and Abrams 2008; Shotola et al. 1992). Prior researches have suggested that significant compositional changes are occurring in oak-dominated forests and Quercus spp. are being replaced by mesophytic, relatively shade-tolerant species such as maple (Acer spp.) (Crow 1988; Dech et al. 2008; Gardiner and Hodges 1988; Tanouchi et al. 1994; Thadami and Ashton 1995; Watt 1919). This dominance shift has significant implications for biodiversity and ecosystems function, and has become an important focus of research and management (McEwan et al. 2011). Will shade-tolerant species ultimately replace oak species and become the dominant canopy species? If this is the case, then why are oak forests still widely distributed and dominant globally? Those questions can be addressed through examining interspecific associations.

Distribution patterns of trees can provide information on structural characteristics and forest dynamics related to the development stage of the forest (Akhavan et al. 2012; Hao et al. 2007). Abundance and composition changes take place during forest development and there are periods of relatively intense interspecific competition that limit coexistence (Mooney et al. 2008) and affect distribution patterns. A major focus of ecological research is to understand the outcomes of biological interactions and ecological process by analyzing spatial distribution patterns and associations (Li et al. 2014a).

In the present study, we analyzed the interspecific associations of eleven dominant tree populations during the development of a virgin old-growth oak broad-leaved mixed forest stand in the Qinling Mountains, China. Overall interspecific association (multiple species) and pairwise interspecific association (two species) were examined. We aim to answer the following questions: (1) are there significant changes in interspecific associations during the development of the forest stand? (2) can interspecific associations contribute to some evidence to explain the dominance of oak forests worldwide? (3) are there significant differences in species distribution during the development of the forest stand? (4) how are species distribution patterns and interspecific associations related?

\section{Methods}

\section{Study area}

The Qinling Mountains are located in a transitional region between the subtropical zone and warm temperate zone of central China. This region has high biodiversity and is ecological important (Yu et al. 2014; Zhao et al. 2014). The forests in the region have been harvested since the 1950s and much of the area is now covered by secondary growth that has low productivity and community stability (Chai and Wang 2016; Chai et al. 2016a; Li et al. 2004). Few oldgrowth forest stands exist in the Qinling Mountains.

The study took place in the western area of the Qinling mounatins on Xiaolong Mountain $\left(104^{\circ} 22^{\prime}-106^{\circ} 43^{\prime}\right.$ E, $\left.33^{\circ} 30^{\prime}-34^{\circ} 49^{\prime} \mathrm{N}\right)$. Altitude ranges between 1442 and 2489 masl. The mountain range (EW length $212.50 \mathrm{~km}$, NS width $146.50 \mathrm{~km}$ ) is a watershed of the upper reaches of the Yangtze and Yellow rivers (Zhao et al. 2008). This area is typical natural secondary forest with high biodiversity and abundant tree cover. The region experiences a mild and humid continental monsoon climate with a mean annual temperature of $9.5^{\circ} \mathrm{C}$. The annual sunshine hours are 2098 and the frost-free period is 185 days. The annual rainfall is $460-800 \mathrm{~mm}$ most of which falls from July to September (Chai et al. 2016b).

\section{Data collection}

A field survey was conducted in the core zone of Baihua forest region from July to September, 2011 in the Xiaolongshan Mountains. Vegetation is a virgin old-growth ( $>100$ years) oak broad-leaved mixed forest, and was representative of the remaining old-growth oak forest at mid-altitude in the Xiaolongshan Mountains. We established a permanent $140 \times 70 \mathrm{~m}$ plot with an average elevation of $1723 \mathrm{~m}$ and a stand density of 887.70 trees $\mathrm{hm}^{-2}$. The plot was established away from roads and villages, where human disturbance is limited (Chai et al. 2016b).

To accurately locate trees, the plot was divided into 50,14 $\times 14 \mathrm{~m}$ subplots (Fig. 1). All trees with a diameter at breast height $(\mathrm{DBH} ; 1.3 \mathrm{~m}) \geq 5 \mathrm{~cm}$ were marked, and their locations were recorded using a total station (TOPCON-GTS-602AF, Fig. 1). Canopy cover, slope aspect, $\mathrm{DBH}$, tree height, and species identity were recorded. To compare the structural differences among individuals within the same population, each tree was assigned a growth stage according to the size of the tree: juvenile $(5 \leq \mathrm{DBH}<10 \mathrm{~cm})$, medium $(10 \leq \mathrm{DBH}<25 \mathrm{~cm})$, and large (DBH $\geq 25 \mathrm{~cm}$ ) (Chai et al. 2016b). This work was conducted based on Forestry Standards "Observation Methodology for Long-term Forest Ecosystem Research" of People's Republic of China (LY/T 1952-2011).

\section{Data analysis}

\section{Importance values (IVs)}

The Importance value (IV) of species is defined as the average of relative density (RD), relative frequency (RF), and relative dominance $(\mathrm{Rd})$ of that species and was 


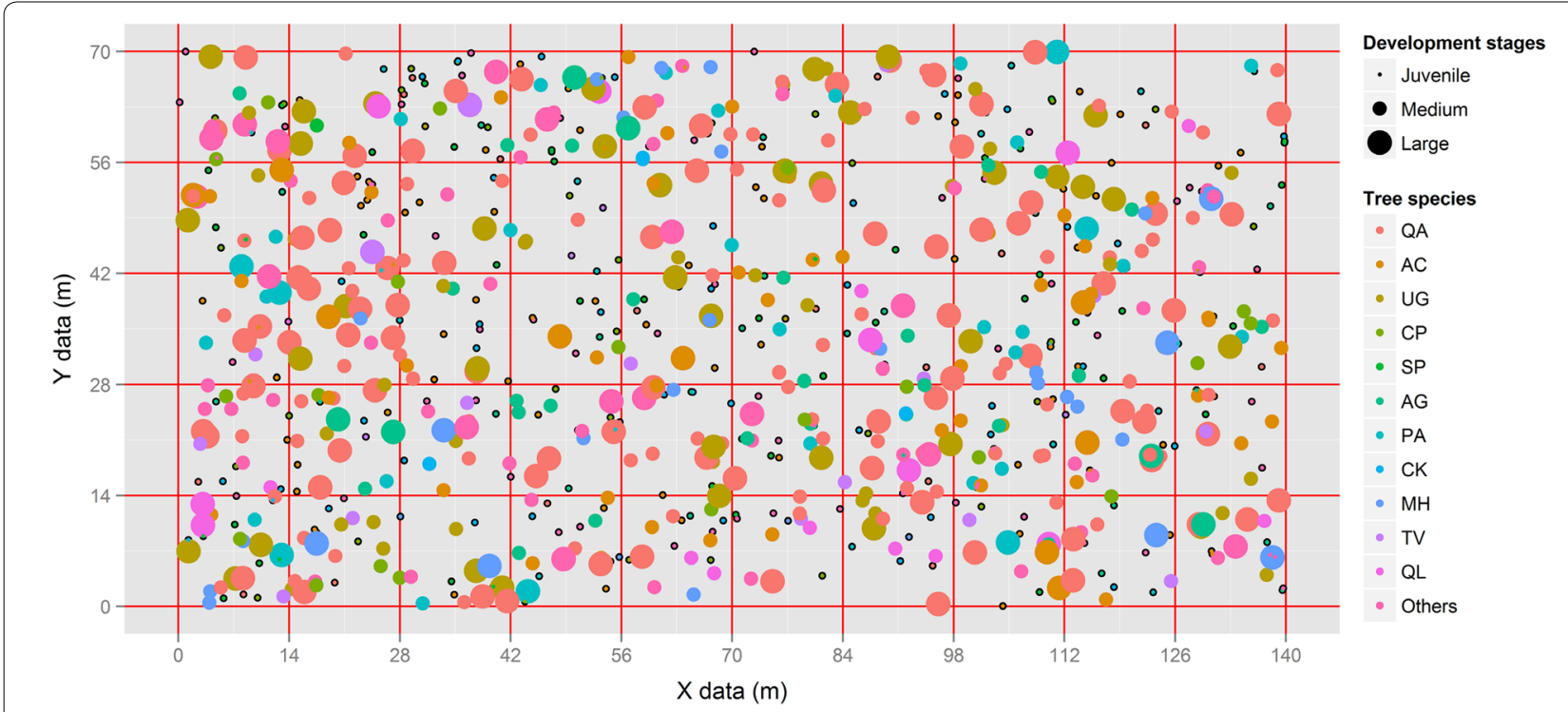

Fig. 1 Spatial distributions of eleven dominant tree populations of different stages in a 0.98 ha $(140 \times 70 \mathrm{~m})$ old-growth oak broad-leaved mixed forest plot in the Qinling Mountains, China. QA is Quercus aliena var. acutiserrata Maxim.; AC is Acer caesium subsp. giraldii (Pax) E. Murr.; UG is Ulmus propinqua Koidz.; CP is Cerasus polytricha (Koehne) Yü et Li; SP is Symplocos paniculata (Thunb.) Miq.; AG is Acer ginnala Maxim.; PA is Pinus armandii Franch.; CK is Crataegus kansuensis Wils.; MH is Malus hupehensis (Pamp.) Rehd.; TV is Toxicodendron vernicifluum (Stokes) F. A. Barkl.; QL is Quercus wutaishanica Blume. Juvenile tree means $5 \mathrm{~cm} \leq \mathrm{DBH}<10 \mathrm{~cm}$, Medium tree means $10 \mathrm{~cm} \leq \mathrm{DBH}<25 \mathrm{~cm}$, and large tree means DBH $\geq 25 \mathrm{~cm}$

calculated using the following equations (Arbainsyah a et al. 2014; Chai et al. 2016a, b):

Density $(D)=\frac{\text { Number of individuals of a species }}{\text { Area of all sample units }}$

Relative abundance $(R D)=\frac{\text { Number of individuals of a species }}{\text { Density for all species }}$ $\times 100 \%$

Frequency $(F)=\frac{\text { Number of quadrats containing a certain specis }}{\text { Total number of quadrats }}$

Relative frequency $(R F)=\frac{\text { Frequency of a certain species }}{\text { Total number of species }} \times 100 \%$

$$
\text { Dominance }(d)=\frac{\text { Basal area of a species }}{\text { Area of all sample units }}
$$

Relative dominance $(R d)=\frac{\text { Dominance of one specis }}{\text { Domiance of all species }} \times 100 \%$

$$
I V=(R D+R F+R d) / 3
$$

\section{Contingency table}

A $2 \times 2$ contingency table or species association table was generated (Table 1). For each pair of species A and B, we can obtain the following: the number of samples in which species $\mathrm{A}$ and B co-occurred

b the number of samples in which species A occurs, but not B

c the number of samples in which species $B$ occurs, but not A

d the number of samples in which neither A nor $B$ are found

$\mathrm{N}$ the total number of samples.

\section{Test of species association (two-species case)}

To test for interspecific associations, a null hypothesis stating that species are independent was used. A corrected Chi square test (Yates's correction formula) was used to test the null hypothesis of independence in the $2 \times 2$ contingency table (Yarranton 1966; Zaal 1993).

$$
\chi^{2}=\frac{N[|a d-b c|-N / 2]^{2}}{(a+b)(c+d)(a+c)(b+d)}
$$

When $\chi^{2}<3.841$, there is no interspecific association; when $3.841 \leq \chi^{2}<6.635$, there are certain associations between species; when $x^{2} \geq 6.635$, there are significant associations between species. When $a d>b c$, the interspecific association is positive, and when $a d<b c$, the interspecific association is negative. 
Table $12 \times 2$ contingency table or species association table

\begin{tabular}{lllll}
\hline & & \multicolumn{2}{c}{ Species B } & \\
\cline { 3 - 4 } & & Present & Absent & \\
\hline Species A & Present & $a$ & $b$ & $m=a+b$ \\
& Absent & $c$ & $d$ & $n=c+d$ \\
& $\sum$ & $r=a+c$ & $s=b+d$ & $N=a+b+c+d$ \\
\hline
\end{tabular}

\section{Measures of species association (two-species case)}

To test the strength of associations and association coefficient $(A C$ ) index (Hurlbert 1969; Ofomata et al. 1999; Su et al. 2015) was used to further verify the results of the Chi square test.

When $a d \geq b c A C=\frac{(a d-b c)}{[(a+b)(b+d)]}$

When $a d<b c$ and $d \geq a A C=\frac{(a d-b c)}{[(a+b)(a+c)]}$

When $a d<b c$ and $d<a A C=\frac{(a d-b c)}{[(b+d)(c+d)]}$

$A C$ index assumes values from 1 for complete positive associations $(b=0, c=0)$ to -1 for complete negative associations ( $a=0, d=0)$. It equals zero when there is no association.

\section{Overall species association (multiple-species case)}

The variance in total species number (or total density of individuals) in samples was compared to the sum of the variance of the individual species using the following equation (Schluter 1984):

$$
V=\frac{S_{T}^{2}}{\sum \delta_{i}^{2}}
$$

$S_{T}^{2}$ is calculated:

$$
s_{T}^{2}=(1 / N) \sum_{j}^{N}\left(T_{j}-t\right)^{2}
$$

where $N=$ the number of samples, $T_{j}=$ the total number of species in sample $j$, and $t=$ the mean number of species per sample.

$\delta_{i}^{2}$ is given by:

$$
\delta_{i}^{2}=(1 / N) \sum_{j}^{N}\left(X_{i j}-t_{j}\right)^{2}
$$

where $X_{i j}=$ the abundance of species $i$ in sample $j$; and $t_{i}=$ the mean abundance of species $i$. When $V=1$ under the assumption of independence, and $V \neq 1$, indicates that the species tend to covary positively $(V>1)$ or negatively $(V<1)$ in their abundances. The significance of the association indices were assessed at $P<0.05$ (Death 2000; Forbes et al. 1994; Schluter 1984).

\section{Uniform angle index (W)}

The uniform angle index $(W)$ describes the degree of regularity for the four neighbors that are nearest to reference tree $i . W$ is defined as the proportion of the angle $(\alpha)$ smaller than the standard angle $\alpha_{0}\left(72^{\circ}\right)$, expressed as:

$W_{i}=\frac{1}{4} \sum_{j=1}^{n} z_{i j}, z_{i j}=\left\{\begin{array}{ll}1 & \text { if } \alpha-\text { angle is smaller than } \alpha_{0} \\ 0, & \text { otherwise }\end{array}\right\}$

$$
\bar{W}=\frac{1}{N_{s p}} W_{i}=\frac{1}{4 N_{s p}} \sum_{i=1}^{N_{s p}} \sum_{j=1}^{4} z_{i j}
$$

where $N_{s p}$ is the number of trees of species sp in the community.

$W$ has a series of flexible values at five different levels $(0.00,0.25,0.50,0.75$, and 1.00$)$, and the average uniform angle index $(\bar{W})$ for the random case was defined by the bounds $(0.475,0.517)$. A $\bar{W}$-value of less than 0.475 corresponds to a regular distribution and values exceeding 0.517 correspond to a clumped distribution (Gadow and Hui 2002; Li et al. 2014b). To eliminate edge effects and improve the accuracy of the uniform angle index, we established a $5 \mathrm{~m}$ buffer zone around the plot. In the statistical analysis, only the trees in the reduced window $(130 \times 60 \mathrm{~m})$ were used as reference trees, and the individual trees in the buffer zone were only considered as nearest neighbors of the trees in the reduced window ( $\mathrm{Li}$ et al. 2014b). This edge correction can individually evaluate each tree to determine whether all $n$ nearest neighbors are truly located within the plot.

$\mathrm{R}$ version 3.1.3 (R Core Team 2015) was used for all statistical analyses. The species association indices were conducted using the "spaa" package (Zhang and Ma 2014), the spatial association and uniform angle index were conducted using "spatstat" package (Baddeley and Turner 2005) and "forestSAS" package (Chai 2016)

\section{Results}

\section{Species composition and importance value (IV)} characteristics

A total of 48 tree species were identified belonging to 29 genera and 16 families (Table 2). The families with the greatest number of species were Rosaceae $(N=12$, $25.00 \%)$, Aceraceae $(N=9,18.75 \%)$, Betulaceae $(N=4$, $8.33 \%)$, Fagaceae $(N=3,6.25 \%)$, Tiliaceae $(N=3$, $6.25 \%)$, and Ulmaceae $(N=3,6.25 \%)$. The number of juvenile tree species was 40 (27 genera, 16 families), medium was 29 ( 20 genera, 14 families), and large was 18 (12 genera, 9 families).

We identified Quercus aliena var. acutiserrata Maxim., Acer caesium subsp. giraldii (Pax) E.Murr., Ulmus propinqua Koidz., Cerasus polytricha (Koehne) Yü et Li, 
Table 2 Composition and importance value (IV) index of the tree species in different development stages in an oldgrowth oak broad-leaved mixed forest

\begin{tabular}{|c|c|c|c|c|c|c|}
\hline \multirow[t]{2}{*}{ Species } & \multirow[t]{2}{*}{ Family } & \multirow[t]{2}{*}{ Density (trees ha ${ }^{-1}$ ) } & \multicolumn{4}{|c|}{ Importance value (\%) } \\
\hline & & & Juvenile & Medium & Large & All \\
\hline Quercus aliena var. acutiserrata Maxim & Fagaceae & 190.82 & $4.79 \pm 0.08$ & $31.57 \pm 0.18$ & $50.7 \pm 0.28$ & $27.13 \pm 0.1$ \\
\hline Acer caesium subsp. giraldii (Pax) E.Murr & Aceraceae & 137.76 & $25.5 \pm 0.17$ & $13.75 \pm 0.14$ & $4.59 \pm 0.16$ & $13.6 \pm 0.08$ \\
\hline Ulmus propinqua Koidz & Ulmaceae & 77.55 & $0.72 \pm 0.03$ & $12.04 \pm 0.15$ & $20.79 \pm 0.25$ & $12.56 \pm 0.09$ \\
\hline Cerasus polytricha (Koehne) Yü et Li & Rosaceae & 60.2 & $9.94 \pm 0.11$ & $6.26 \pm 0.1$ & - & $5.58 \pm 0.05$ \\
\hline Symplocos paniculata (Thunb.) Miq. & Symplocaceae & 58.16 & $14.47 \pm 0.13$ & $0.54 \pm 0.04$ & - & $4.81 \pm 0.04$ \\
\hline Acer ginnala Maxim. & Aceraceae & 57.14 & $6.66 \pm 0.1$ & $8.46 \pm 0.12$ & $1.93 \pm 0.06$ & $6.67 \pm 0.05$ \\
\hline Pinus armandii Franch. & Pinaceae & 56.12 & $7 \pm 0.11$ & $7.07 \pm 0.09$ & $2.62 \pm 0.07$ & $6.18 \pm 0.06$ \\
\hline Crataegus kansuensis Wils & Rosaceae & 47.96 & $14.73 \pm 0.14$ & $0.39 \pm 0.02$ & - & $4.7 \pm 0.04$ \\
\hline Malus hupehensis (Pamp.) Rehd & Rosaceae & 32.65 & $1.21 \pm 0.04$ & $5.19 \pm 0.1$ & $3.93 \pm 0.12$ & $3.73 \pm 0.05$ \\
\hline Toxicodendron vernicifluum (Stokes) F. A. Barkl. & Anacardiaceae & 22.45 & $0.89 \pm 0.04$ & $4.55 \pm 0.08$ & $0.56 \pm 0.03$ & $2.6 \pm 0.04$ \\
\hline Quercus wutaishanica Blume & Fagaceae & 18.37 & $0.23 \pm 0.02$ & $2.52 \pm 0.07$ & $3.32 \pm 0.1$ & $2.95 \pm 0.06$ \\
\hline Tilia paucicostata Maxim & Tiliaceae & 12.24 & $0.88 \pm 0.03$ & $0.77 \pm 0.03$ & $0.74 \pm 0.03$ & $0.98 \pm 0.02$ \\
\hline Acer cappadocicum Gled & Aceraceae & 11.22 & $1.04 \pm 0.04$ & $1.13 \pm 0.03$ & - & $0.72 \pm 0.02$ \\
\hline Lindera obtusiloba Bl. & Lauraceae & 11.22 & $1.66 \pm 0.05$ & $0.83 \pm 0.03$ & - & $0.87 \pm 0.02$ \\
\hline Acer davidii Franch. & Aceraceae & 10.2 & $1.17 \pm 0.04$ & $1.08 \pm 0.03$ & - & $0.79 \pm 0.02$ \\
\hline Morus alba Linn. & Moraceae & 10.2 & $1.48 \pm 0.04$ & $0.1 \pm 0.01$ & - & $0.62 \pm 0.02$ \\
\hline Acer tetramerum var. betulifolium (Maxim.) Rehd & Aceraceae & 7.14 & $1.22 \pm 0.04$ & - & - & $0.36 \pm 0.01$ \\
\hline Carya cathayensis Sarg & Juglandaceae & 6.12 & $0.77 \pm 0.03$ & $0.27 \pm 0.02$ & $1.53 \pm 0.08$ & $0.84 \pm 0.03$ \\
\hline Kalopanax septemlobus (Thunb.) Koidz & Araliaceae & 5.1 & $0.55 \pm 0.03$ & $0.71 \pm 0.03$ & - & $0.41 \pm 0.02$ \\
\hline Tilia oliveri Szyszyl & Tiliaceae & 4.08 & - & $0.44 \pm 0.02$ & $0.48 \pm 0.02$ & $0.4 \pm 0.01$ \\
\hline Meliosma cuneifolia var. glabriuscula Cufod & Sabiaceae & 4.08 & $0.48 \pm 0.02$ & - & - & $0.16 \pm 0.01$ \\
\hline Acer elegantulum Fang et P. L. Chiu & Aceraceae & 4.08 & $0.3 \pm 0.02$ & $0.29 \pm 0.02$ & $0.26 \pm 0.02$ & $0.27 \pm 0.01$ \\
\hline Padus racemosa (Linn.) Gilib & Rosaceae & 3.06 & $0.43 \pm 0.02$ & $0.1 \pm 0.01$ & - & $0.14 \pm 0.01$ \\
\hline Amygdalus persica $\mathrm{L}$. & Rosaceae & 3.06 & $0.28 \pm 0.02$ & $0.34 \pm 0.02$ & $0.32 \pm 0.02$ & $0.34 \pm 0.02$ \\
\hline Ulmus macrocarpa Hance & Ulmaceae & 3.06 & - & $0.29 \pm 0.02$ & $0.43 \pm 0.03$ & $0.31 \pm 0.02$ \\
\hline Tilia oliveri & Tiliaceae & 2.04 & $0.31 \pm 0.02$ & - & - & $0.09 \pm 0$ \\
\hline Betula platyphylla Suk & Betulaceae & 2.04 & - & $0.13 \pm 0.01$ & $0.41 \pm 0.03$ & $0.2 \pm 0.01$ \\
\hline Corylus heterophylla var. sutchuenensis Franch & Betulaceae & 2.04 & $0.18 \pm 0.01$ & - & - & $0.08 \pm 0.01$ \\
\hline Pyrus betulifolia Bge. & Rosaceae & 2.04 & $0.22 \pm 0.02$ & - & $0.37 \pm 0.03$ & $0.22 \pm 0.01$ \\
\hline Acer henryi Pax & Aceraceae & 2.04 & - & $0.42 \pm 0.02$ & - & $0.17 \pm 0.01$ \\
\hline Pyrus xerophila Yü & Rosaceae & 2.04 & $0.31 \pm 0.02$ & - & - & $0.09 \pm 0$ \\
\hline Corylus heterophylla Fisch & Betulaceae & 2.04 & $0.48 \pm 0.02$ & - & - & $0.13 \pm 0.01$ \\
\hline Spiraea alpina Pall & Rosaceae & 2.04 & $0.14 \pm 0.01$ & $0.19 \pm 0.01$ & - & $0.12 \pm 0.01$ \\
\hline Rhus potaninii Maxim. & Anacardiaceae & 2.04 & - & $0.22 \pm 0.02$ & $0.32 \pm 0.02$ & $0.18 \pm 0.01$ \\
\hline Pinus tabulaeformis Carr. & Pinaceae & 2.04 & - & - & $0.72 \pm 0.04$ & $0.33 \pm 0.02$ \\
\hline Staphylea holocarpa Hemsl. & Staphyleaceae & 1.02 & $0.29 \pm 0.02$ & - & - & $0.06 \pm 0$ \\
\hline Quercus spinosa David ex Franchet & Fagaceae & 1.02 & $0.21 \pm 0.02$ & - & - & $0.09 \pm 0.01$ \\
\hline Celtis koraiensis Nakai & Ulmaceae & 1.02 & $0.16 \pm 0.01$ & - & - & $0.05 \pm 0$ \\
\hline Sorbus hupehensis Schneid. & Rosaceae & 1.02 & $0.11 \pm 0.01$ & - & - & $0.04 \pm 0$ \\
\hline Morus australis Poir. & Moraceae & 1.02 & $0.16 \pm 0.01$ & - & - & $0.04 \pm 0$ \\
\hline Acer palmatum Thunb. & Aceraceae & 1.02 & $0.17 \pm 0.01$ & - & - & $0.04 \pm 0$ \\
\hline Prunus salicina Linn. & Rosaceae & 1.02 & $0.18 \pm 0.01$ & - & - & $0.05 \pm 0$ \\
\hline Carpinus cordata Bl. & Betulaceae & 1.02 & $0.15 \pm 0.01$ & - & - & $0.03 \pm 0$ \\
\hline Fraxinus paxiana Lingelsh. & Oleaceae & 1.02 & $0.18 \pm 0.01$ & - & - & $0.06 \pm 0$ \\
\hline Acer tsinglingense Fang et Hsieh. & Aceraceae & 1.02 & - & $0.12 \pm 0.01$ & - & $0.07 \pm 0$ \\
\hline Sorbus alnifolia (Sieb. et Zucc.) K. Koch & Rosaceae & 1.02 & $0.2 \pm 0.01$ & - & - & $0.04 \pm 0$ \\
\hline Amelanchier sinica (Schneid.) Chun & Rosaceae & 1.02 & $0.15 \pm 0.01$ & - & - & $0.04 \pm 0$ \\
\hline Fraxinus platypoda Oliver & Oleaceae & 1.02 & - & $0.22 \pm 0.02$ & - & $0.06 \pm 0$ \\
\hline
\end{tabular}

Juvenile tree means $5 \mathrm{~cm} \leq \mathrm{DBH}<10 \mathrm{~cm}$, Medium tree means $10 \mathrm{~cm} \leq \mathrm{DBH}<25 \mathrm{~cm}$, Large tree means $\mathrm{DBH} \geq 25 \mathrm{~cm}$, and All refers to all tree populations with $\mathrm{DBH} \geq 5 \mathrm{~cm}$ in the studied plot 
Symplocos paniculata (Thunb.) Miq., Acer ginnala Maxim., Pinus armandii Franch., Crataegus kansuensis Wils., Malus hupehensis (Pamp.) Rehd., Toxicodendron vernicifluum (Stokes) F. A. Barkl., and Quercus wutaishanica Blume as the dominant tree populations (first 11 tree populations in Table 2) accounting for $85.5 \%$ of the total overstory density (DBH $\geq 5 \mathrm{~cm}$ ).

Species importance values showed obvious differences at different development stages. The tree species $Q$. aliena var. acutiserrata, $U$. propinqua, and $Q$. wutaishanica increased, while, A. caesium subsp. giraldii, P. armandii, T. paucicostata, and A. elegantulum decreased as the forest stand developed (Table 2).

\section{Population structure of dominant tree populations}

The forest stand showed a reverse J-shaped distribution of tree diameters when all species were pooled. A total of $41.30 \%$ of individuals were juvenile trees with a DBH class of $5-10 \mathrm{~cm}$ (Fig. 2). Extra-large (DBH $\geq 45 \mathrm{~cm}$ ) trees species were concentrated in populations of $Q$. aliena var. acutiserrata, $U$. propinqua, A. ginnala and $Q$. wutaishanica (Fig. 2).

The 11 dominant tree populations showed great variability in abundance at different growth stages (Fig. 2). The size frequency distribution of the tree species indicated that $Q$. aliena var. acutiserrata, $U$. propinqua, $M$. hupehensis, T. vernicifluum, and Q. wutaishanica had a unimodal distribution. While, A. caesium subsp. giraldii, C. polytricha, S. paniculata, A. ginnala, P. armandii, and $C$. kansuensis showed an inverse J-shaped population structure suggesting they were the most dominant juvenile trees (Fig. 2).

\section{Overall species associations}

The overall interspecific association of 11 dominant tree populations presented in Table 3. For the total dominant tree populations, the overall negative association $(V<1)$ was significant.

For both the juvenile and medium tree stages the association was not significant. By contrast, large trees showed a significantly negative overall association. The overall association among different development stages was negative and suggests that the interspecific competition increases with stand development.

\section{Test of species association}

The $\chi^{2}$ test showed that among total dominant tree populations, 21 pairs (38.18\%) showed a positive association, 31 pairs $(56.36 \%)$ showed a negative association, and 3 pairs (5.45\%) showed no association (Fig. 3d). A statistically significant positive association was found between C. kansuensis and $M$. hupehensis $\left(X^{2}=6.88, P<0.01\right)$, and a significantly negative association between $S$. paniculata and C. kansuensis $\left(\chi^{2}=-4.02,0.01<P<0.05\right)$.

The proportion of negative associations increased slightly from juvenile $(52.70 \%)$ to medium $(56.40 \%)$ to large (71.40\%) trees suggesting that negative associations increase with stand age (Fig. $3 \mathrm{a}-\mathrm{c})$. In the juvenile tree populations, significantly positive associated pair were $U$. propinqua and A. ginnala $\left(\chi^{2}=4.52,0.01<P<0.05\right)$, and negative associated pair were $A$. ginnala and $P$. armandii $\left(x^{2}=-4.11,0.01<P<0.05\right)$. In the medium tree populations there were no significantly associated pairs. In the large tree populations the significantly positive associated pair was $Q$. aliena var. acutiserrata and A. caesium subsp. giraldii $\left(\chi^{2}=-3.89,0.01<P<0.05\right)$. Overall, there were few significant associations among dominant tree populations. This suggests that species associations were weak for most species pairs, and the distribution of tree species is independent.

\section{Measures of species association}

The $A C$ index showed that among total dominant tree populations, 22 pairs (40\%) showed positive association and 33 pairs $(60 \%)$ showed negative associations. Highly positive associations $(0.5 \leq A C \leq 1)$ were $Q$. aliena var. acutiserrata with $U$. propinqua, $P$. armandii, $M$. hupehensis, T. vernicifluum, and Q. wutaishanica; and the species pair C. kansuensis and M. hupehensis. Highly negative associations $(-1 \leq A C \leq-0.5)$ were $Q$. aliena var. acutiserrata with $A$. caesium subsp. giraldii, C. polytricha, S. paniculata, A. ginnala, and C. kansuensis. The $A C$ index showed that species pair C. kansuensis and $M$. hupehensis had the higher positive association $(A C=0.62)$, and $U$. propinqua and $T$. vernicifluum had the higher negative association $(A C=-0.46)$, which was consistent with the results of the $\chi^{2}$ test (Fig. 4d).

The $A C$ index of juvenile trees showed that 20 pairs (36.36\%) had positive association, 32 pairs (58.18\%) showed negative association, and 3 pairs $(5.45 \%)$ had no association. Highly positive associations $(0.5 \leq A C \leq 1)$ of $A$. caesium subsp. giraldii were found with $U$. propin$q u a$ and $Q$. wutaishanica. Highly negative associations $(-1 \leq A C \leq-0.5)$ of $Q$. wutaishanica were found with most other species except $A$. caesium subsp. giraldii, and the species pairs $U$. propinqua and $M$. hupehensis, $U$. propinqua and T. vernicifluum, A. ginnala and P. armandii, A. ginnala and M. hupehensis, and M. hupehensis and T. vernicifluum also exhibited highly negative associations. $A C$ index showed that the species pair $U$. propinqua and $A$. ginnala had positive association $(A C=0.14)$, and $U$. propinqua and $T$. vernicifluum had negative association $(A C=-0.56)$, which were consistent with the results of the $\chi^{2}$ test (Fig. 4a). 


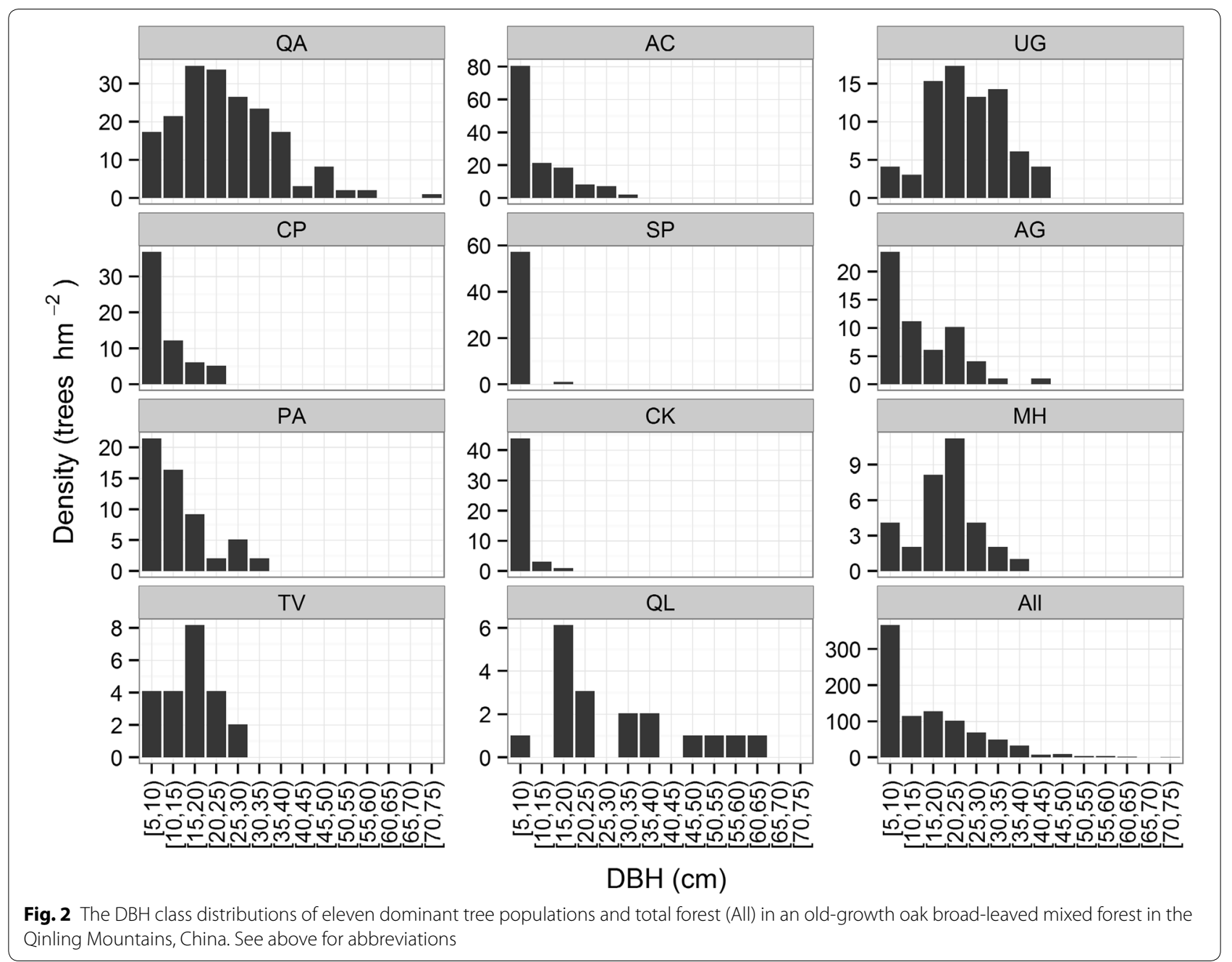

Table 3 The overall association among dominant tree populations in different development stages

\begin{tabular}{lllllll}
\hline Development stages & $\boldsymbol{\delta}_{\boldsymbol{i}}^{\mathbf{2}}$ & $\boldsymbol{S}_{\boldsymbol{T}}^{\mathbf{2}}$ & Variance ratio $(\boldsymbol{V})$ & W statistic & $\boldsymbol{\chi}^{\mathbf{2}}\left(\boldsymbol{\chi}_{\mathbf{0 . 9 5}}^{\mathbf{2}} \mathbf{N}, \boldsymbol{\chi}_{\mathbf{0 . 0 5}}^{\mathbf{2}}, \mathbf{N}\right)$ & Overall association \\
\hline Juvenile & 1.785 & 1.320 & 0.740 & 36.979 & $(34.765,67.505) \mathrm{N}=50$ & No significant negative \\
Medium & 1.918 & 1.560 & 0.813 & 40.678 & No significant negative \\
Large & 1.003 & 0.680 & 0.678 & 31.857 & Significantly negative \\
All & 2.130 & 1.434 & 0.673 & 33.659 & Significantly negative \\
\hline
\end{tabular}

In the development stage of medium trees, $A C$ association showed that 18 pairs $(32.73 \%)$ showed positive association, 36 pairs (65.46 \%) showed negative association, and $1(1.82 \%)$ was no association. Highly positive associations $(0.5 \leq A C \leq 1)$ were $Q$. aliena var. acutiserrata with S. paniculata, C. kansuensis, and T. vernicifluum; A. caesium subsp. giraldii with $S$. paniculata, C. kansuensis. Highly negative associations $(-1 \leq A C \leq-0.5)$ were $Q$. wutaishanica with $A$. caesium subsp. giraldii, $S$. paniculata, A. ginnala, P. armandii and C. kansuensis; $S$. paniculata with Q. aliena var. acutiserrata, C. polytricha, A. ginnala, P. armandii, C. kansuensis, M. hupehensis, T. vernicifluum, (Fig. 4b).

In the development stage of large trees, $A C$ association showed that 8 pairs $(28.57 \%)$ showed positive association, 20 pairs (71.43 \%) showed negative association. Highly positive associations $(0.5 \leq A C \leq 1)$ were $Q$. aliena var. acutiserrata with $A$. ginnala, $T$. vernicifluum. Highly negative association $(-1 \leq A C \leq-0.5)$ were $T$. vernicifluum with $A$. caesium subsp. giraldii, $U$. 
a

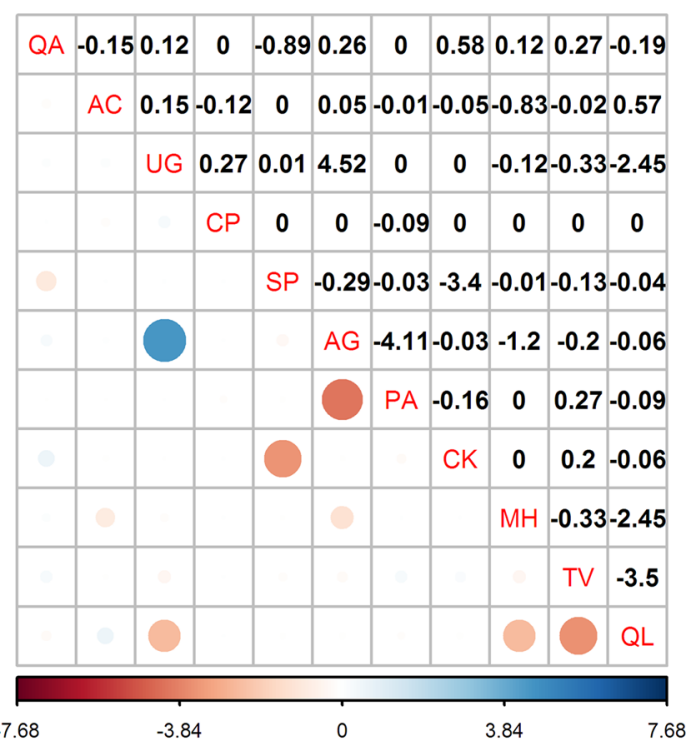

b

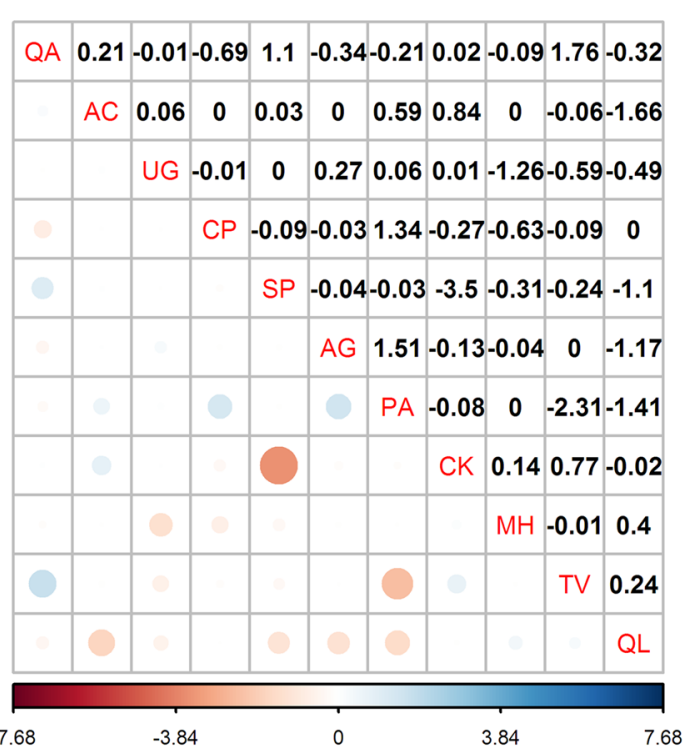

C

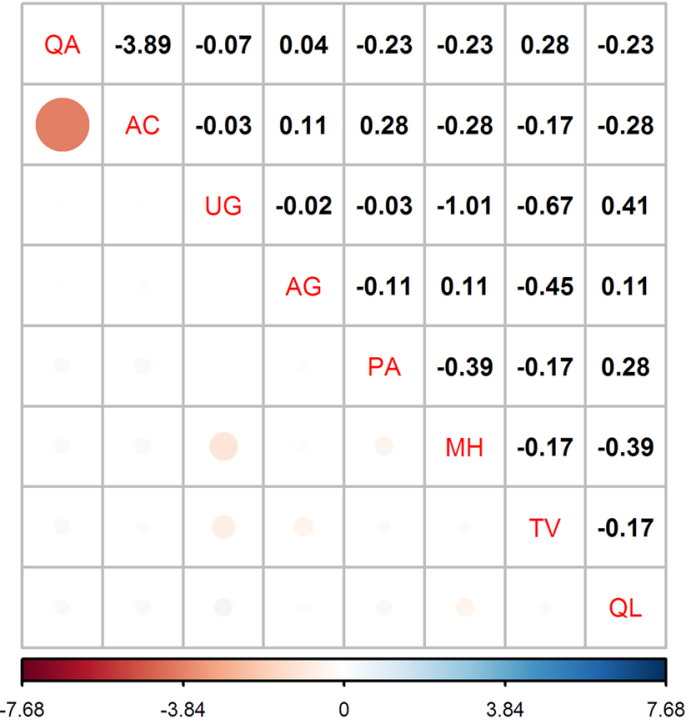

d

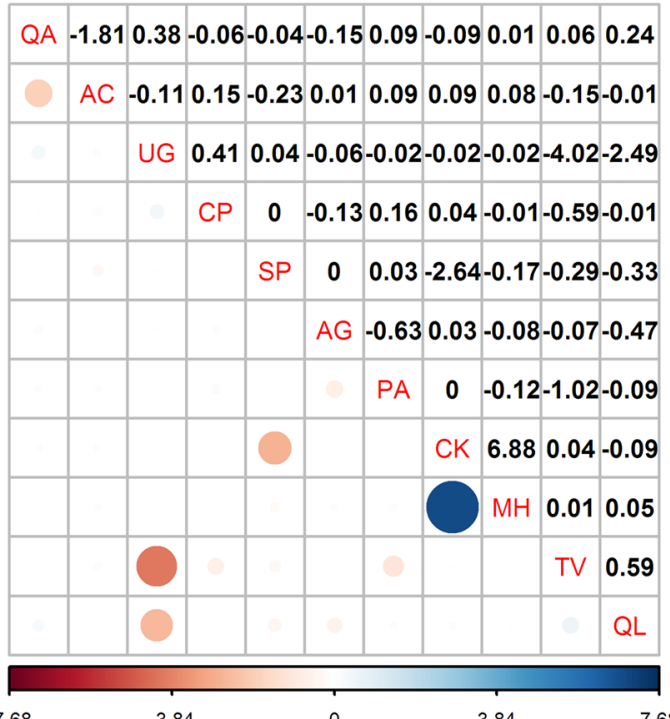

Fig. 3 Semi-matrix graph of interspecific correction $x^{2}$ test of association of dominant tree populations in an old-growth oak broad-leaved mixed forest in the Qinling Mountains, China. $\mathbf{a}$ is development stage of juvenile tree $(5 \mathrm{~cm} \leq \mathrm{DBH}<10 \mathrm{~cm})$; $\mathbf{b}$ is development stage of medium tree $(10 \mathrm{~cm} \leq \mathrm{DBH}<25 \mathrm{~cm})$; $\mathbf{c}$ is development stage of large tree $(\mathrm{DBH} \geq 25 \mathrm{~cm})$; and $\mathbf{d}$ is total forest $(\mathrm{DBH} \geq 5 \mathrm{~cm})$. When $x^{2} \geq 6.635$, extra significant positive association; $3.841 \leq x^{2}<6.635$, significant positive association; $-3.841 \leq x^{2}<3.841$, no association, independent distribution; $-6.635 \leq x^{2}<-3.841$, significant negative association; $x^{2}<-6.635$, Extra significant negative association. See above for abbreviations

propinqua, A. ginnala, P. armandii, M. hupehensis, and $Q$. wutaishanica; $M$. hupehensis with $Q$. wutaishanica, $P$. armandii; and the species pair A. ginnala and P. armandii. $A C$ index showed that Q. aliena var. acutiserrata and A. caesium subsp. giraldii with higher negative association $(A C=-0.41)$, which was consistent with the results of the $\chi^{2}$ test (Fig. $4 \mathrm{c}$ ).

\section{Discussion}

Interspecific competition increased with the development of the old-growth oak broad-leaved mixed forest stand. Negative associations among species are indicative of interspecific competition (Rejmánek and Lepš 1996). Negative interspecific associations dominated overall interspecific association (multiple species) and pairwise 
a

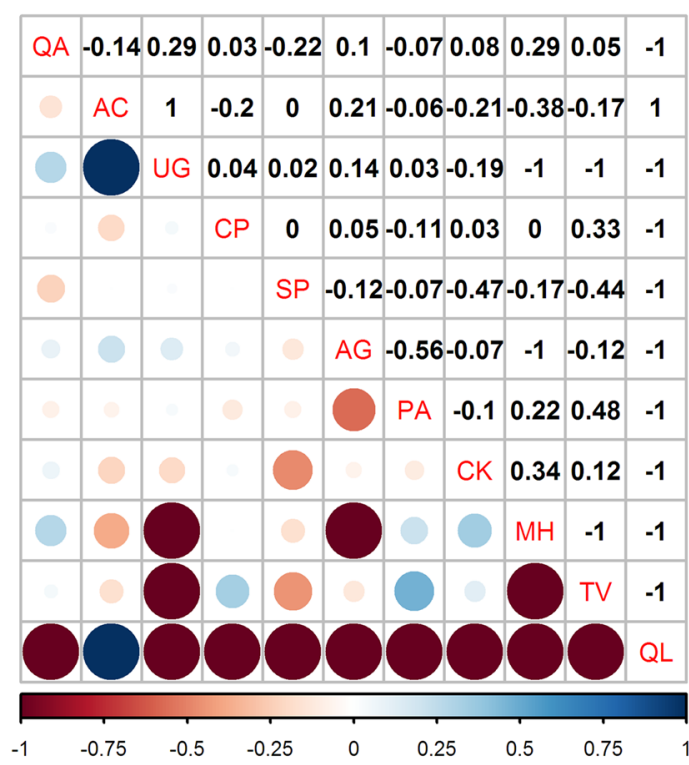

C

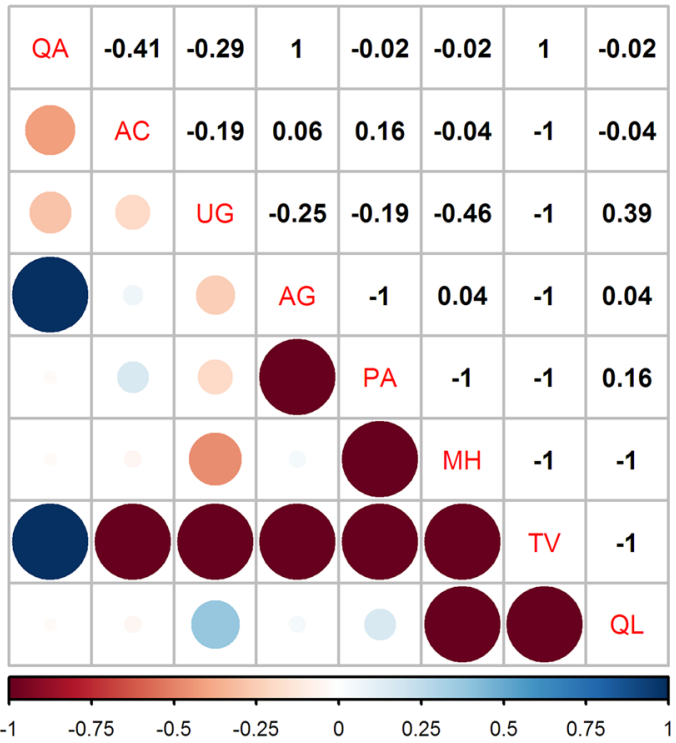

b

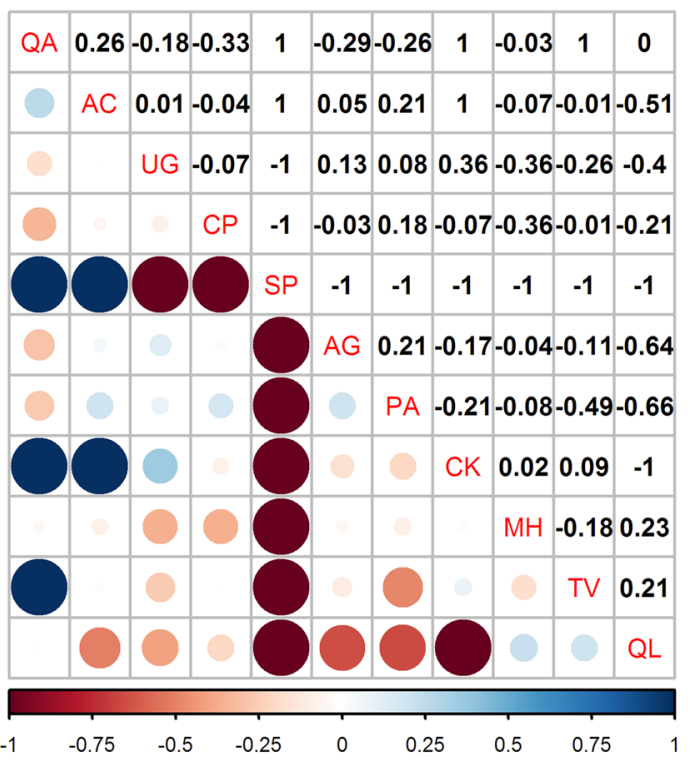

d

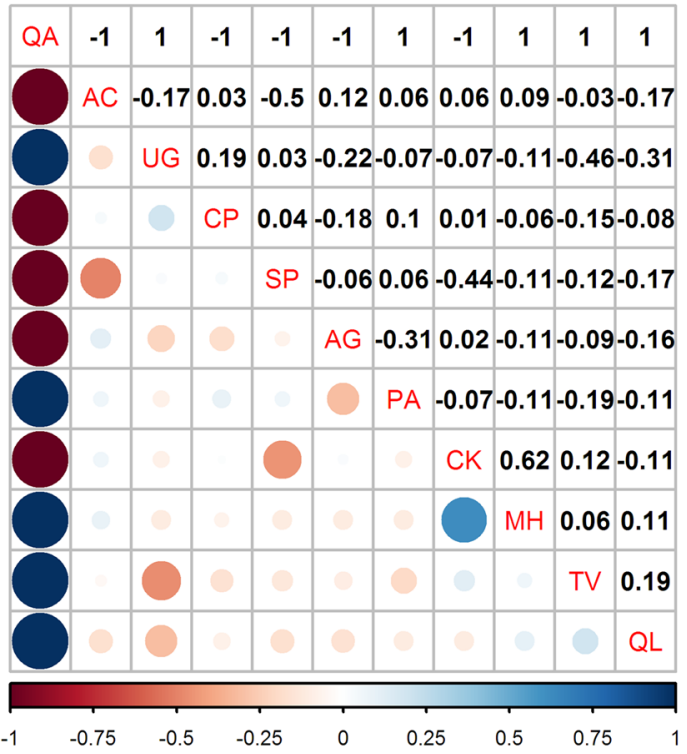

Fig. 4 Semi-matrix graph of AC interspecific coefficient of dominant tree populations in an old-growth oak broad-leaved mixed forest in the Qinling Mountains, China. $\mathbf{a}$ is development stage of juvenile tree $(5 \mathrm{~cm} \leq \mathrm{DBH}<10 \mathrm{~cm})$; $\mathbf{b}$ is development stage of medium tree $(10 \mathrm{~cm} \leq \mathrm{DBH}<25 \mathrm{~cm})$; $\mathbf{c}$ is development stage of large tree $(\mathrm{DBH} \geq 25 \mathrm{~cm})$; and $\mathbf{d}$ is total forest $(\mathrm{DBH} \geq 5 \mathrm{~cm})$. See above for abbreviations

interspecific association (two species) in the old-growth oak broad-leaved mixed forest of the Xiaolong Mountains. This suggests that interspecific competition is very intense, which is similar to the findings by Ma et al. (2014) and Fraver et al. (2014) who found that interspecific competition continues to influence forest processes and structure in undisturbed old-growth forests. The increasing negative associations with increasing forest stages are consistent with the harsh-benign hypothesis (Peckarsky 1983). The harsh-benign hypothesis predicts that competitive interactions are more likely in stable environments and negative interspecific associations occur more often in stable sites than the unstable sites (Death 2000; Peckarsky 1983). The same results have been reported in many other studies (Hao et al. 2007; Liu et al. 2014). Old-growth oak broad-leaved mixed forests over 100 years old have reached a late-successional stage and the $A C$ index network corroborated this theory (Fig. 5). Forests dominated by Q. aliena var. acutiserrata, T. vernicifluum, and A. ginnala, are typical stable forest 

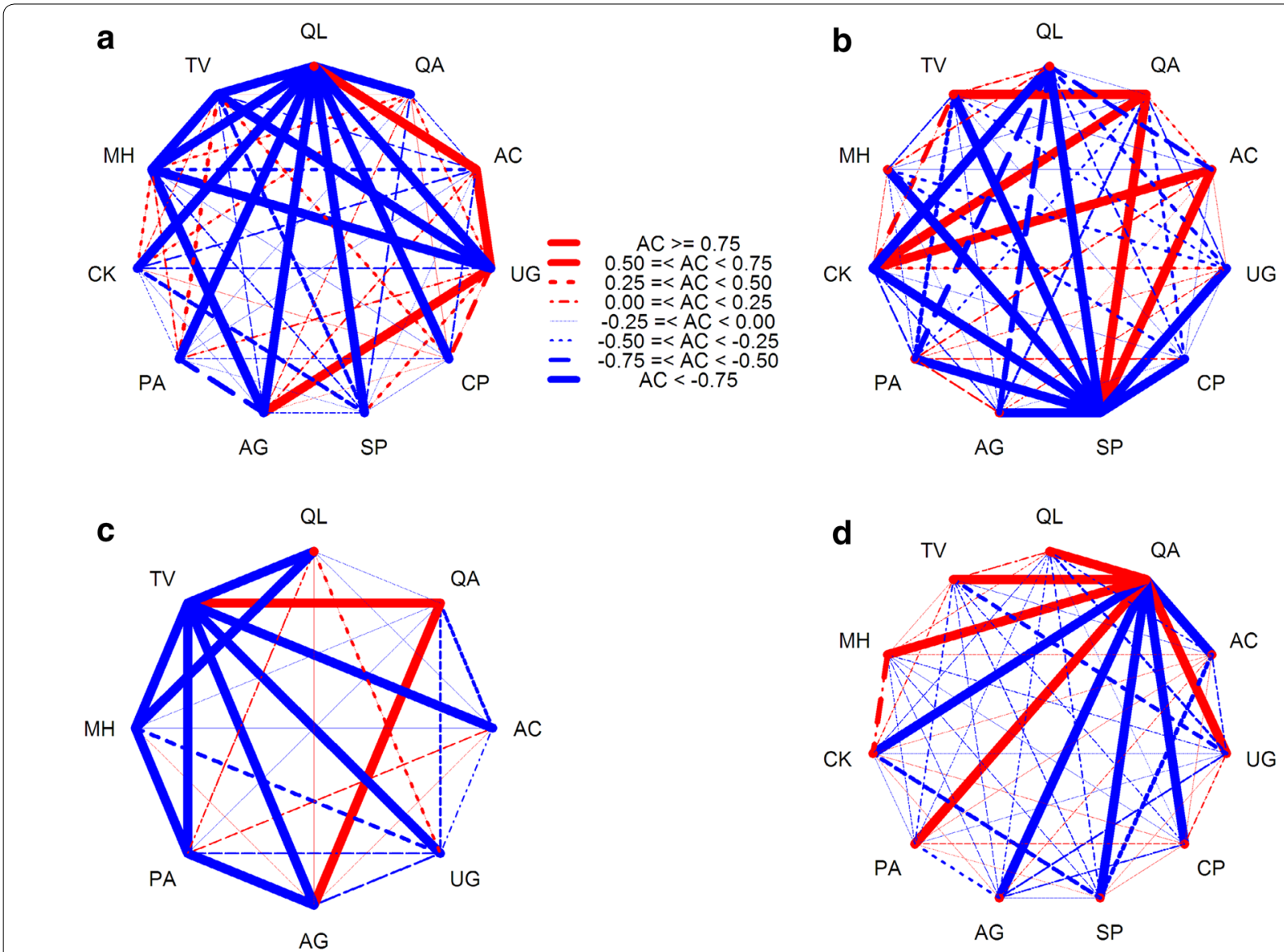

Fig. 5 Network of Association coefficient index in an old-growth oak broad-leaved mixed forest in the Qinling Mountains, China. a is development stage of juvenile tree $(5 \mathrm{~cm} \leq \mathrm{DBH}<10 \mathrm{~cm})$; $\boldsymbol{b}$ is development stage of medium tree $(10 \mathrm{~cm} \leq \mathrm{DBH}<25 \mathrm{~cm})$; $\mathbf{c}$ is development stage of large tree $(\mathrm{DBH} \geq 25 \mathrm{~cm})$; and $\mathbf{d}$ is total forest $(\mathrm{DBH} \geq 5 \mathrm{~cm})$. See above for abbreviations

communities distributed in mid-mountain zones of Qinling Mountains (Lei et al. 1996). Our results further support the harsh-benign hypothesis that species interactions are more common in stable sites.

Oak forests are distributed widely around the world, in part because it is a typical K-selected species. Mixed and pure stands of oak can adapt to a wide variety of site and soil conditions (Abrams et al. 1998; Alvarez et al. 2009; Collins and Battaglia 2008), however, globally Quercus species generally have poor natural regeneration in the forests where they occur (Crow 1988; Dech et al. 2008; Gardiner and Hodges 1988; Tanouchi et al. 1994; Thadami and Ashton 1995; Watt 1919) and this same trend was observed in the oak forests of the Qinling Mountains (Chai and Wang 2016; Yu et al. 2013a). $\mathrm{Yu}$ et al. (2013b) noted that there could be strong competition for seed dispersers among co-occurring species, so variation in seed size and other seed traits may shape the behavior of dispersers. Quercus are large seed species with a low seedset and is a rodent-dispersed species.
Previous studies have shown that oak seeds were usually transported to adjacent pine forests by rodents, resulting poor natural regeneration in the oak forests where they occur (Chang et al. 2012; Yu et al. 2013b). The calculated importance values may support this phenomenon as there were significantly fewer juvenile oak trees than other species (Table 2). However, the hard shell and high nutritional content (e.g., protein, fat, and starch) of oak seeds (Chang et al. 2012) result in high-quality offspring and competitive ability for those that do establish. This phenomenon is reflected in the importance values of medium and large trees and results in its dominance in older forest stands (Table 2). In addition, long-living tree species are able to maintain their dominance in a forest stand even if they only regenerate successfully once over many years (Warner and Chesson 1985). The findings of Hou et al. (2004) in a Quercus-Betula forest in northern China showed that the longevity of Quercus combined with its dominance in the stand can compensate for the low regeneration and allow them to persist. Yu et al. 


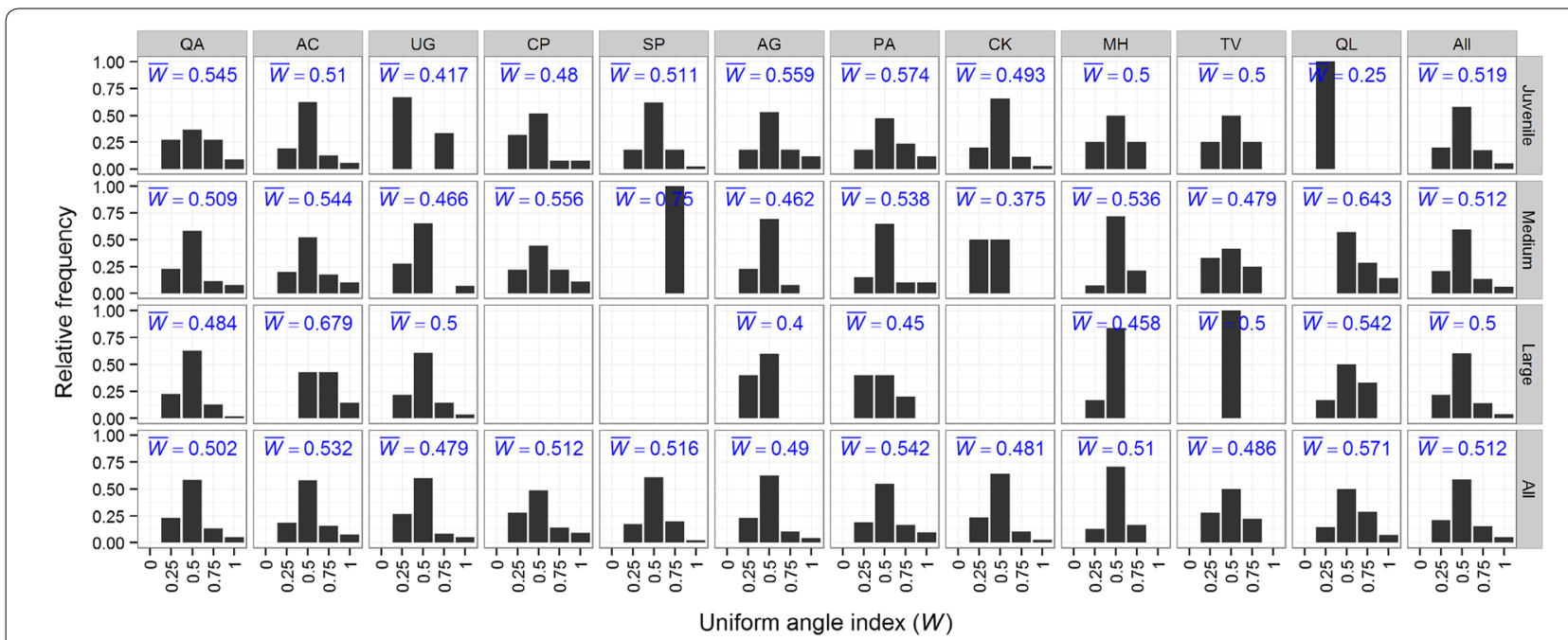

Fig. 6 Distribution of uniform angle index for dominant tree populations in an old-growth oak broad-leaved mixed forest in the Qinling Mountains, China. $\bar{W}$ is the average value of uniform angle index. See above for abbreviations

(2013a) further corroborated this result by finding that $Q$. aliena var. acutiserrata regeneration was not affected by low establishment. These results all suggest that despite low regeneration, oak populations will maintain their dominance if there are no large-scale disturbances in the Qinling Mountains.

Observed distribution patterns of tree species maybe the result of ecological niche differentiation due to the intense interspecific competition. Species interactions influence ecological processes such as growth, regeneration and mortality which in turn influence tree distribution (Bieng et al. 2013; Kang et al. 2014). Our results showed that there are obvious differences among the eleven dominant tree populations during the development of the forest stand but the overall distribution is random (Fig. 6). This suggests that the forest is in a stable state. Some researches explain this phenomenon as a long-term species interaction between the plant community and environment (Hao et al. 2007; Liu et al. 2014; Nathan 2006; Schoolmaster 2013). We conclude that the shift from clumped to random as the forest stand developed maybe evidence for niche differentiation and selection of species composition through the sieve of interspecific relations. This is supported by Zaal (1993) and Getzin et al. (2006) who found that spatial distribution and tree size are not independent patterns but are commonly affected by the interspecific competition. Parrish and Bazzaz (1982) showed that early successional species of plants have broad, overlapping niche occupation on many gradients, whereas later successional species show more niche differentiation. Call and Nilsen (2003) and Su et al. (2015) also support the theory that species pairs with positive associations share similar resources and exhibit a wide niche overlap, while negative association indicate that plants have different habitat and resource requirements.

\section{Conclusion}

Old growth oak (Quercus spp.) forests are distributed widely around the world in part due to oak being a typical K-selected species. K-selected species produce fewer, high-quality offspring with higher survival rates, strong competitive ability, and longevity. Interspecific competition was intense during forest development and was the main factor driving succession, which supports the harsh-benign hypothesis that interspecific competition is more common in stable sites. The resulting distribution shifted from clumped to random, likely as a result of intense interspecific competition creating ecological niche differentiation.

\section{Authors' contributions \\ All authors contributed substantially to the work reported here. The four authors participated in the design of the study. ZC and CS analyzed the data and wrote the manuscript. DW wrote and reviewed the manuscript. WL per- formed the sample collection and reviewed the manuscript. All authors read and approved the final manuscript. \\ Author details \\ ${ }^{1}$ College of Forestry, Northwest A \& F University, No.3 Taicheng Road, Yangling 712100, Shaanxi, People's Republic of China. ${ }^{2}$ State Key Laboratory of Soil Erosion and Dryland Farming on the Loess Plateau, Northwest A \& F University, Yangling 712100, Shaanxi, People's Republic of China. ${ }^{3}$ Institution of Forestry, Xiaolongshan Forest Experiment Bureau, Tianshui 741020, Gansu, People's Republic of China.}

\section{Acknowledgements}

The authors thank the anonymous reviewers for their valuable comments on the manuscript and Alison Beamish at the University of British Columbia for 
her assistance with English language and grammatical editing of the manuscript. We also thank the Xiaolongshan National Forest Ecosystem Research Station at Tianshui city, Gansu Province, for its strong support of our work. This study was funded by the National Natural Science Funds of China (Grant No. 31470644), Special Research Program for Public-Welfare Forestry of State Forestry Administration of China (Grant No. 201204504), and CFERN and GENE Award Funds on Ecological Paper.

\section{Competing interests}

The authors declare that they have no competing interests.

Received: 18 June 2016 Accepted: 25 August 2016

Published online: 01 September 2016

\section{References}

Abrams MD, Copenheaver CA (1999) Temporal variation in species recruitment and dendroecology of an old-growth white oak forest in the Virginia Piedmont, USA. For Ecol Manag 124:275-284

Abrams MD, Ruffner CM, DeMeo TE (1998) Dendroecology and species coexistence in an old-growth Quercus-Acer-Tilia talus slope forest in the central Appalachians, USA. For Ecol Manag 106:9-18

Akhavan R, Sagheb-Talebi K, Zenner EK, Safavimanesh F (2012) Spatial patterns in different forest development stages of a virgin old-growth Oriental beech forest in the Caspian region of Iran. Eur J For Res 131:1355-1366

Alvarez R, Munoz A, Pesqueira XM, Garcia-Duro J, Reyes O, Casal M (2009) Spatial and temporal patterns in structure and diversity of Mediterranean forest of Quercus pyrenaica in relation to fire. For Ecol Manag 257:1596-1602

Arbainsyah HH, Kustiawan W, de Snoo GR (2014) Structure, composition and diversity of plant communities in FSC-certified, selectively logged forests of different ages compared to primary rain forest. Biodivers Conserv 23:2445-2472

Baddeley A, Turner R (2005) Spatstat: an r package for analyzing spatial point patterns. J Stat Soft 12:1-42

Bieng MAN, Perot T, de Coligny F, Goreaud F (2013) Spatial pattern of trees influences species productivity in a mature oak-pine mixed forest. Eur J For Res 132:841-850

Cabaret J, Hoste H (1998) Comparative analysis of two methods used to show interspecific associations in naturally acquired parasite nematode communities from the abomasum of ewes. Vet Parasitol 76:275-285

Call LJ, Nilsen ET (2003) Analysis of spatial patterns and spatial association between the invasive tree-of-heaven (Ailanthus altissima) and the native black locust (Robinia pseudoacacia). Am Midl Nat 150:1-14

Chai ZZ (2016) forestSAS, An R package for forest spatial structure analysis systems. https://github.com/Zongzheng/forestSAS

Chai ZZ, Wang DX (2016) Environmental influences on the successful regeneration of pine-oak mixed forests in the Qinling Mountains, China. Scand J For Res 31:368-381

Chai ZZ, Fan DF, Wang DX (2016a) Environmental factors and underlying mechanisms of tree community assemblages of pine-oak mixed forests in the Qinling Mountains, China. J Plant Biol 59:357-367

Chai ZZ, Sun CL, Wang DX, Liu WZ, Zhang CS (2016b) Spatial structure and dynamics of predominant populations in a virgin old-growth oak forest in the Qinling Mountains, China. Scand J For Res. doi:10.1080/02827581. 2016.1183703

Chang G, Jin TZ, Pei JF, Chen XN, Zhang B, Shi ZJ (2012) Seed dispersal of three sympatric oak species by forest rodents in the Qinling Mountains, Central China. Plant Ecol 213:1633-1642

Cole LC (1949) The measurement of Interspecific association. Ecology 30:411-424

Collins B, Battaglia LL (2008) Oak regeneration in southeastern bottomland hardwood forest. For Ecol Manag 255:3026-3034

Cowell CM, Hoalst-Pullen N, Jackson MT (2010) The limited role of canopy gaps in the successional dynamics of a mature mixed Quercus forest remnant. J Veg Sci 21:201-212

Crow TR (1988) Reproductive mode and mechanisms for self replacement of northern red oak (Quercus rubra) — a review. For Sci 34:19-40
Death RG (2000) Habitat stability and interspecific associations among invertebrate assemblages in New Zealand streams. NZ J Mar Freshwat Res 34:501-506

Dech JP, Robinson LM, Nosko P (2008) Understorey plant community characteristics and natural hardwood regeneration under three partial harvest treatments applied in a northern red oak (Quercus rubra L.) stand in the Great Lakes-St. Lawrence forest region of Canada. For Ecol Manag 256:760-773

Forbes M, Weatherhead PJ, Bennett GF (1994) Blood parasites of blue grouse - variation in prevalence and patterns of interspecific association. Oecologia 97:520-525

Fraver S, D'Amato AW, Bradford JB, Jonsson BG, Jonsson M, Esseen PA (2014) Tree growth and competition in an old-growth Picea abies forest of boreal Sweden: influence of tree spatial patterning. J Veg Sci 25:374-385

Gadow KV, Hui G (2002) Characterizing forest spatial structure and diversity. In: Proc of the SUFOR international workshop: sustainable forestry in temperate regions. pp. 20-30

Galbraith S, Martin W (2005) Three decades of overstory and species change in a mixed mesophytic forest in eastern Kentucky. Castanea 70:115-128

Gardiner ES, Hodges J (1988) Growth and biomass distribution of cherrybark oak (Quercus pagoda Raf.) seedlings as influenced by light availability. For Ecol Manag 108:127-134

Getzin S, Dean C, He FL, Trofymow JA, Wiegand K, Wiegand T (2006) Spatial patterns and competition of tree species in a Douglas-fir chronosequence on Vancouver Island. Ecography 29:671-682

Hao ZQ, Zhang J, Song B, Ye J, Li BH (2007) Vertical structure and spatial associations of dominant tree species in an old-growth temperate forest. For Ecol Manag 252:1-11

Haukisalmi V, Henttonen H (1998) Analysing interspecific associations in parasites: alternative methods and effects of sampling heterogeneity. Oecologia 116:565-574

Hou JH, Mi XC, Liu CR, Ma KP (2004) Spatial patterns and associations in a Quercus-Betula forest in northern China. J Veg Sci 15:407-414

Hurlbert SH (1969) A coefficient of interspecific association. Ecol Lett 50:1-9

Kang D, Guo YX, Ren CJ, Zhao FZ, Feng YZ, Han XH, Yang GH (2014) Population structure and spatial pattern of main tree species in secondary betula platyphylla forest in Ziwuling Mountains, China. Sci Rep 4:6873

Lei RD, Peng H, Chen CG (1996) Types and phytoenosis of natural secondary forests at huoditang forest region. J Northwest For Coll 11:43-52

Li W, Ji W, Liu J (2004) A study of sustainable forest management technology in Qinling forest area. J Northwest For Univ 19:184-188

Li L, Ye WH, Wei SG, Lian JY, Huang ZL (2014a) Spatial patterns and associations between species belonging to four genera of the Lauraceae family. PLoS One 9(11):e111500

Li Y, Hui G, Zhao Z, Hu Y, Ye S (2014b) Spatial structural characteristics of three hardwood species in Korean pine broad-leaved forest-Validating the bivariate distribution of structural parameters from the point of tree population. For Ecol Manag 314:17-25

Liu YY, Li FR, Jin GZ (2014) Spatial patterns and associations of four species in an old-growth temperate forest. J Plant Interact 9:745-753

Ma YD, Liu WZ, Zhao ZH, Shi XL, Li AM (2014) Change analysis of spatial pattern and correlation for Quercus aliena var. acuteserrata forest population in Xiaolongshan Mountains. Acta BotBoreal OccidentSin 34:1878-1886

Maihaiti M, Zhang WJ (2014) A mini review on theories and measures of interspecific associations. Selforganizology 1:206-210

McCune B, Cottam G (1985) The successional status of a southern Wisconsin oak woods. Ecology 66:1270-1278

McEwan RW, Dyer JM, Pederson N (2011) Multiple interacting ecosystem drivers: toward an encompassing hypothesis of oak forest dynamics across eastern North America. Ecography 34:244-256

Mooney KA, Jones P, Agrawal AA (2008) Coexisting congeners: demography, competition, and interactions with cardenolides for two milkweed-feeding aphids. Oikos 117:450-458

Nathan R (2006) Long-distance dispersal of plants. Science 313:786-788

Nowacki GJ, Abrams MD (2008) The demise of fire and "mesophication" of forests in the eastern United States. Bioscience 58:123-138

Ofomata VC, Overholt WA, Van Huis A, Egwuatu RI, Ngi-Song AJ (1999) Niche overlap and interspecific association between Chilo partellus and Chilo orichalcociliellus on the Kenya coast. Entomol Exp Appl 93:141-148

Parrish JAD, Bazzaz FA (1982) Competitive interactions in plant communities of different successional ages. Ecology 63:314-320 
Peckarsky BL (1983) Biotic interactions or abiotic limitations? A model of lotic community structure. In: Fontaine TD, Bartell SM (eds) Dynamics of lotic ecosystems. Ann Arbor Scientific Publications, Michigan

Petritan IC, Marzano R, Petritan AM, Lingua E (2014) Overstory succession in a mixed Quercus petraea-Fagus sylvatica old growth forest revealed through the spatial pattern of competition and mortality. For Ecol Manag 326:9-17

R Core Team (2015) R: a language and environment for statistical computing. $R$ Foundation for Statistical Computing, Vienna. http://www.R-project.org/

Rejmánek M, Lepš J (1996) Negative association can reveal interspecific competition and reversal of competitive hierarchies during succession. Oikos 76:161-168

Schluter D (1984) A variance test for detecting species associations, with some example applications. Ecology 65:998-1005

Schoolmaster DR (2013) Resource competition and coexistence in heterogeneous metacommunities: many-species coexistence is unlikely to be facilitated by spatial variation in resources. Peerj 1:e136

Shotola SJ, Weaver G, Robertson P, Ashby W (1992) Sugar maple invasion of an old-growth oak-hickory forest in southwestern Illinois. Am Midl Nat 127:125-138

Su SJ, Liu JF, He ZS, Zheng SQ, Hong W, Xu DW (2015) Ecological species groups and interspecific association of dominant tree species in Daiyun mountain National Nature Reserve. J Mt Sci 12:637-646

Tanouchi H, Sato T, Takeshita K (1994) Comparative-studies on acorn and seed ling dynamics of 4 quercus species in an evergreen broad-leaved forest. J Plant Res 107:153-159

Thadami R, Ashton P (1995) Regeneration of banj oak (Quercus leucotrichophora A. Camus) in the central Himalaya. For Ecol Manag 78:217-224

Wang XG, Wiegand T, Hao ZQ, Li BH, Ye J, Lin F (2010) Species associations in an old-growth temperate forest in north-eastern China. J Ecol 98:674-686
Warner RR, Chesson PL (1985) Coexistence mediated by recruitment fluctuations: a field guide to the storage effect. Am Nat 125:769-787

Watt AS (1919) On the causes of failure of natural regeneration in British oakwoods. J Ecol 7:173-203

Wiegand T, Gunatilleke S, Gunatilleke N (2007) Species associations in a heterogeneous Sri lankan dipterocarp forest. Am Nat 170:E77-E95

Yarranton GA (1966) A plotless method of sampling vegetation. J Ecol 54:229-237

Yu F, Wang DX, Shi XX, Chen LL, Huang QP, Song B (2013a) Species composition and regeneration characteristics of main woody plant seedlings in a pine-oak mixed forest in Qinling Mountains. Acta Bot Boreal OccidentSin 33:592-598

Yu F, Wang DX, Shi XX, Yi XF, Li G (2013b) Seed dispersal by small rodents favors oak over pine regeneration in the pine-oak forests of the Qinling Mountains, China. Scand J For Res 28:540-549

Yu F, Wang DX, Yi XF, Shi XX, Huang YK, Zhang HW, Zhang XP (2014) Does animal-mediated seed dispersal facilitate the formation of Pinus armandiiQuercus aliena var. acuteserrata forests? PLoS One 9(2):e89886

Zaal K (1993) Plant-species associations in alpine-subnival vegetation patches in the central caucasus. J Veg Sci 4:297-302

Zhang JL, and Ma KP (2014) spaa: an R package for computing species association and niche overlap. Research Progress of Biodiversity Conservation in China. vol. 10, pp. 165-174

Zhao Z, Hui G, Yuan S, Liu W (2008) Tree species diversity and structure characteristics of Quercus aliena var. acuteserrata natural forest on Xiaolongshan. For Res 21:605-610

Zhao XG, Ma CH, Xiao L (2014) The vegetation history of Qinling Mountains, China. Quat Int 325:55-62

\section{Submit your manuscript to a SpringerOpen ${ }^{\odot}$ journal and benefit from:}

- Convenient online submission

- Rigorous peer review

- Immediate publication on acceptance

- Open access: articles freely available online

- High visibility within the field

- Retaining the copyright to your article

Submit your next manuscript at springeropen.com 